\title{
Exploration of Fungal Infection in Agricultural Grains, Aflatoxin and Zearalenone Synthesis under pH Stress
}

\author{
Marei A. Hamed, T. M Abdel Ghany*, Nadeem I. Elhussieny and M.A.Nabih
}

Biology Department, Faculty of Science, Jazan University, KSA, Botany and Microbiology Department, Faculty of Science, AL-Azhar University, Cairo, Egypt

*Corresponding author

\section{A B S T R A C T}

Keywords

Exploration, fungal infection, agricultural grains, mycotoxins, $\mathrm{pH}$.

Article Info

Accepted:

22 March 2016

Available Online:

10 April 2016
Mycoflora of 25 grains samples collected from southern governorates of KSA were investigated. Fungal plates count for collected samples ranged from 0 up to $9900 \mathrm{CFU} / \mathrm{g}$. The moisture content as an essential factor that affect fungal content of grains was also investigated and was variable among samples with range from 2.75 to $8.22 \%$. Sixteen fungal species were identified among them Aspergilli, Penicilli and Fusaria dominate. A. niger, $A$. flavus and $F$. oxysporium showed high frequency among isolates, respectively. A. flavus and $F$. oxysporium were cultivated at different $\mathrm{pH}$ values and aflatoxins (B1, B2, G1 and G2) and zearalenone were detected. Maximum aflatoxins were produced at $\mathrm{pH} 5$ while zearalenone was at $\mathrm{pH} 7$.

\section{Introduction}

The growth of toxigenic fungi can adversely affect grain quality and even produce mycotoxins of food safety concern, which should be sensitively monitored and controlled during grain storage (Huan-Chen et al., 2015). Surveillance for mycotoxins and mycotoxigenic fungi is critical for maintaining high quality grains and grain products (Sarlin et al., 2006). Fungal identification is very important to provide information about which mycotoxins could be present (Maenetje and Dutton, 2007;
For example, Lund and Frisvad (2003) found that samples of wheat and barley grains showing a percentage infestation of Penicillium verrucosum higher than that (7\%) indicated by Ochratoxin A presence.

Grain spoilage and mycotoxin contamination caused by toxigenic fungi are significant food safety problems (Frisvad \& Thrane, 2004; Pitt et al., 2013). Grains fungal contamination have been carefully studied in several areas, and several grain types. Montes et al. (2009) investigated 
fungal colonies on yellow and white maize grains. The major fungi encountered were Fusarium sp., Penicillium sp., and Aspergillus sp. When compared with the yellow hybrids, white hybrids had 34, 52 and $22 \%$ less infection by Fusarium verticillioides, Aspergillus flavus, and Aspergillus niger, respectively, and almost the double infection with Penicillium sp. Infection of maize kernels by toxigenic fungi remains a challenging problem despite the research progress (Munkvold, 2003). During grain storage, xerophilic fungi, such as Aspergillus glaucus and Aspergillus restrictus, always grow at low water activity (aw < 0.75) in grain and are always the most predominant fungal species at the beginning of storage and have relatively less effect on grain quality (Anke et al., 1980).

However, the growth of Aspergillus flavus, Aspergillus ochraceus and Penicillium sp. can seriously spoil stored grain, and even produce toxigenic or carcinogenic metabolites, which can pose a health risk to humans and animals (Nesci et al., 2003; Amézqueta et al., 2012). A total of 101 isolates of $A$. flavus and $A$. parasiticus originating from acid treated feeding grain in Sweden were identified according to conidial ornamentation. $A$. flavus was the most common $(71 \%$ of all isolates) of the two species (Holmberg et al., 1989). Fusarium sp., were the most abundant species detected in maize kernels, followed by Aspergillus sp. of sections Flavi and Nigri and by Penicillium sp. Among Fusarium species, F. verticillioides was the most prevalent species, as detected by PCR directly on the kernels and on the fungi isolated from the kernels, followed by $F$. proliferatum and $F$. subglutinans (Covarelli et al., 2011).

Wheat were also found to be contaminated in variable amounts by potentially toxigenic fungi including Aspergillus, Alternaria and Fusarium (Tournas and Katsoudas, 2008). Microorganism get on grain in different ways, most often with dust from soil, from the surface of plant remnants during harvesting, transportation, storage and processing (Klich, 2002). Thirty samples of coffee beans were collected from different places of Jeddah, Saudi Arabia to determine and identify fungal population. Twenty six species belonging to 7 genera were isolated.

The most prevalent genera were Aspergillus and Penicillium, while Fusarium, Mucor, Rhizopus and Alterneria were recovered in moderate incidences (Bokhari and Aly 2009). Mycotoxigenic fungi including Aspergillus, Fusarium, and Penicillium genera are responsible for the majority of agricultural mycotoxin contamination. These fungi are common components of the microbial flora associated with many agronomic crops, including corn and sorghum (Palumbo et al., 2008). Aflatoxins occur in temperate and tropical regions around the world, depending on which fungal species are present. They can affect many food supplies including cereals, nuts, dried fruit, coffee, cocoa, spices, oil seeds, dried peas, beans, fruits, and, in particular, apples (Abdel-Azeem et al., 2015).

More than 20 different aflatoxins were identified, those belonging to the two major groups $B$ and $G$ are frequently found in contaminated food, especially peanuts and maize (Ehrlich et al., 2007; Sherif et al., 2009; Velazhahan et al., 2010; ). However, aflatoxins are genotypically specific, they could also be produced by one or more fungal species (Ioannou-Kakouri et al., 2004), and in some cases, one species can form more than one aflatoxins (Frisvad, 1994). Zearalenone (ZEA) is produced by a variety of Fusarium species, including $F$. 
graminearum, $F$. culmorum, $F$. cerealis, $F$. equiseti, $F$. crookwellense and $F$. semitectum, which are common soil fungi, in temperate and warm countries, and are regular contaminants of cereal crops worldwide (Bennett and Klich, 2003). Wheat contamination with ZEA is a worldwide problem where several reports documented the presence of ZEA in wheat samples of Brazil, Switzerland, Netherlands, Bulgaria and Germany in a level ranged from 2 to $2000 \mu \mathrm{g} . \mathrm{kg}-1$ (Furlong et al., 1995; Bucheli et al., 1996; Vrabcheva et al., 1996; Schollenberger et al., 2005). This study was undertaken to recongnize the frequency and a relative percentage of fungal species in grains produced and stored in Jazan rejoin, Saudi Arabia, in order to use this information to consider possible mycotoxin occurrence in this area. Also, the objective of the current study was to explore the production aflatoxins and Zearalenone under $\mathrm{pH}$ stress.

\section{Material and Methods}

\section{Samples collection}

A total of 25 samples of different grains were collected from markets, local stores, agricultural cooperatives and farm fields from different districts of Jazan governorate, Saudi Arabia Samples were brought to the laboratory in sterile plastic bags and kept at $5^{\circ} \mathrm{C}$. All samples were subjected to mycological analysis.

\section{Isolation and identification of fungi}

Fungal isolates were purified and transferred onto Potato Dextrose Agar (PDA) to study the macro- and micro-morphological characteristics. All the isolates of fungal species were identified up to the species using keys and manuals (Raper and Fennell 1965; Booth 1977; Samson et al., 1981;
Barnett and Hunter 1998; Leslie and Summerell 2006). The isolation frequency (Fr) and relative density (RD) of species were calculated as follows:

Fr $(\%)=$ No. of samples of occurrence of a species/ Total No. of samples x 100

$\mathrm{RD}(\%)=$ No. of isolated genus or species/ Total No. of isolated fungi $\mathrm{x} 100$

\section{Mycotoxins production conditions}

Aspergillus flavus and Fusarium oxysporium were inoculated separately in $250 \mathrm{ml}$ Erlynmer conical flasks containing sterile $2 \%$ wheat natural medium. Flasks were adjusted at different $\mathrm{pH}$ values prior sterilization by autoclave at $121^{\circ} \mathrm{C}$ for 15 min. Inoculated flasks were incubated at $30^{\circ} \mathrm{C}$ for 10 days in dark.

\section{Mycotoxins assay}

Microtitre plate enzyme-linked immunosorbent assay (ELISA) reader (automated Chem-well) Aspergillus and Fusarium mycotoxins test kit were used to ELISA analyses. The samples were analyzed using the Aflatoxin B1, B2, G1, G2 and Zearalenone test procedure which was described by company(r-biopharm) producer (Enzyme Immunoassay for the quantitative analysis of aflatoxins, 1999 and Leszczynska et al., 2001). Ten $\mathrm{ml}$ of blended fungal broth has been sub-sampled with $20 \mathrm{ml}$ of $70 \%$ methanol and vortex for 10 min by magnetic stirrer. The extract was filtrated by Whatman no.1 filter paper and then diluted as $5 \mathrm{ml}$ filtered solution, $15 \mathrm{ml}$ distilled water and $0.25 \mathrm{ml}$ Tween 20. The solution was mixed by magnetic stirrer for 2min. $50 \mu$ loxins $(5,10,20,45 \mathrm{ppb})$ standard solutions and $50 \mu \mathrm{l}$ prepared test samples were added into separate wells of micro-titer plate. Plates were incubated at room temperature. The liquid was then 
removed completely from the wells, the each well was washed with $250 \mu \mathrm{l}$ washing PBS-Tween-Buffer ( $\mathrm{pH}$ 7.2) and this was repeated two times. Subsequently, enzyme substrate $(50 \mu \mathrm{l})$ and Chromogen (tetramethyl-benzidine, $50 \mu \mathrm{l}$ ) were added to each well and incubated for 30min at room temperature in the dark. $100 \mu \mathrm{l}$ of the stop reagent $\left(1 \mathrm{M} \mathrm{H} \mathrm{H}_{2} \mathrm{SO}_{4}\right)$ was added and the absorbance was measured at $450 \mathrm{~nm}$ in ELISA reader.

\section{Result and Discussion}

Saudi Arabia climate is quite harsh, dry desert with extreme temperatures and climatically it is not very ideal for farming. In the past many agricultural programs were initiated to gain food security, ensure selfsufficiency and improve rural livelihoods. Saudia Arabia has been successful in raising yields of several important crops (Al-Shayaa et al., 2012). Poor storage experiences and unfavorable environmental conditions during pre- and postharvest handling of these crops were responsible for the contamination and colonization by mycotoxin producing and non producing fungi. Therefore studies on identification, frequency and their relative percentage are very important and required for further studies on fungi particularly mycotoxin producing fungi and their epidemiological significance in cereal crops cultivated and stored in Saudi Arabia.

Mould growth is determined by several environmental factors (temperature, composition of the gas atmosphere, substrate properties, including moisture content and water activity and $\mathrm{pH}$ ) that markedly affect the composition of the mycoflora in feeds (Marin et al., 2000). In the current study fungal flora of 25 grains samples collected from Saudia Arabia southern governorate were investigated. Fungal count and moisture content of each sample in terms of colony forming units (CFU) per gram dry weight and percentage, respectively, were recorded (Table 1, Figure 1). Grain moisture content was a critical factor that influence establishment of the fungi. Mycological examination revealed the occurrence of 16 species of fungi belonging to 8 different genera. Identified fungal species included five Aspergilli (A. flavus, A. fumigates, A. niger, $A$. ochraceous, A. tamari), three Penicilli ( $P$. chrysogenum, $P$. notatum, $P$. oxalicum), two Fusaria ( $F$. moniliforme, $F$. oxysporum), and two Mucor (Mucor racemosus and unidentified species) in addition to Chaetomium thermophilum, Rhizopus stolonifer, Syncephalastrum racemosum and Ulocladium chartarum. Hashem (1990) reported 29 species of fungi were isolated from normal and discolored grains of barley in Saudi Arabia. The most common genera were Ulocladium (four species); Alternaria, Aspergillus and Drechslera (three species); Curvularia, Fusarium, Mucor, Penicillium and Syncephalastrum (two species). Mycological studies conducted to detect the colony forming unit (CUF) of fungi in 25 samples of grains revealed that some samples of different grains exhibited no clear relationship between number of $\mathrm{CFU}$ and diversity in fungal species detected, where some grains containing highest $\mathrm{CFU}$ but containing lowest fungal species. For example, sample 22 containing $98 \times 10^{2}$ $\mathrm{CUF} / \mathrm{g}$ grains but containing two fungal species $A$. flavus and $F$. moniliforme. On the other hand sample 11 containing $34.1 \times 10^{2}$ $\mathrm{CUF} / \mathrm{g}$ but containing 7 fungal species. In the present study, different samples of grains containing the same fungal species, A. niger, Fusarium oxysporum were detected in sample 3 and 20. While A. niger, $F$. oxysporum, A. flavus were detected in sample 7, 10, 16 and 20. Also samples (12 and 15) (21 and 23) containing the same 
fungal species (Table 2). Sample 24 contains no fungal species. Wheat and other grain samples in Saudi Arabia were separately analyzed to identify the presence of fungi and their mycotoxins (Muneera, 2014), it was found that samples containing common Alternaria, Aspergillus and Fusari $u m$. Another study which correlates with the data obtained in the present work is that Aspergillus and Fusarium were isolated from grain samples (barley, rice, wheat, white corn and yellow corn),collected from different localities of Riyadh region, Kingdom of Saudi Arabia, and were screened for their toxigenic potential (Amira et al., 2012).

Among fungal isolates A. niger, A. flavus and $F$. oxysporums showed high frequency within collected samples (84, 68 and $40 \%$ with a relative percentage of $27.27,22.08$ and $12.99 \%$, respectively). The other fungal genera include A. fumigatus (12\%), A. ochraceous (28\%), A. tamarii (8\%), Chaetomium thermophilum (4\%), F. moniliforme (8\%), P. chrysogenum (12\%) and other fungal isolates with the different level of frequency and relative percentage (Figure 2). The results of this investigation are similar to those obtained by earlier workers and show that The predominant Aspergillus species isolated were A. flavus (72.7\%) and $A$. niger (59.1\%) with the relative percentage of 51.1 and $33.3 \%$, respectively on sorghum grains (Sreenivasa et al., 2010). The mycological profile of the retail wheat flour selling in different markets at Jeddah (Kingdom of Saudi Arabia) was studied by Gashgari et al. (2010). The most common genera were Aspergillus (isolated from $70 \%$ of the tested samples), Penicillium (30\%), Eurotium (14\%), and in a lesser extent Fusarium (20\%) and Alternaria (18\%). Under Jazan region conditions, four Aspergillus species were isolated and identified from stored wheat flour; the isolated species prevalence being A. flavus, A. niveus, A. terreus, and $A$. niger by rate $44.5 \%, 37.8 \%, 10.9 \%$ and $6.7 \%$, respectively ( Bosly and Kawanna, 2014).

Fig.1 Fungal Colonies Isolated from 25 Samples of Collected Grains, Control, Non Inoculated Plates Containing Growth Medium.

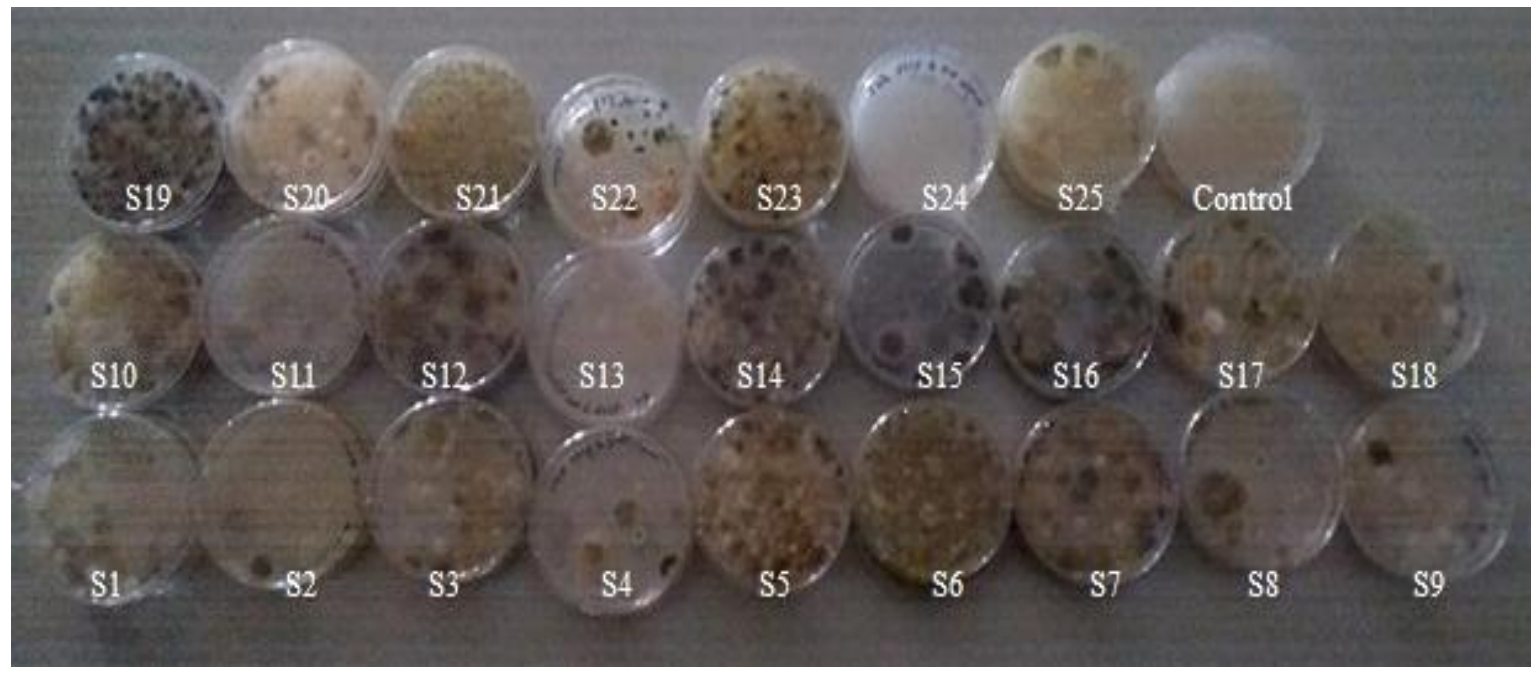


Table.1 Moisture Content and Number of Fungal Isolates (Cfu) in the Collected Grains Samples, Collected from Various Regions.

\begin{tabular}{|c|c|c|c|c|}
\hline $\begin{array}{l}\text { Sample } \\
\text { No. }\end{array}$ & Grain type & Collection site & $\begin{array}{l}\text { Moisture content } \\
(\%)\end{array}$ & $\begin{array}{c}\text { Plate count } \\
\left(\mathrm{CFU}^{*} 10^{2} / \mathrm{g}\right)\end{array}$ \\
\hline 1 & Sorghum bicolor (Red) & Jazan & 7.38 & 3.65 \\
\hline 2 & Sorghum bicolor (White) & Jazan & 4.955 & 5.25 \\
\hline 3 & Sorghum bicolor (White) & Damad & 5.53 & 15.25 \\
\hline 4 & Sorghum bicolor (White) & Sabya & 3.18 & 8.1 \\
\hline 5 & Sorghum bicolor (White) & Abu Arish & 7.5 & 14.45 \\
\hline 6 & Vigna sp. & Jazan & 2.79 & 82 \\
\hline 7 & Sorghum bicolor (Red) & Abu Arish & 2.75 & 48 \\
\hline 8 & Helianthus annuus & Abu Arish & 7.99 & 3.55 \\
\hline 9 & Triticum sp. & Jazan & 3.16 & 6.6 \\
\hline 10 & Triticum sp. & Abu Arish & 3.56 & 4.4 \\
\hline 11 & Zea mays & Jazan & 6.53 & 34.1 \\
\hline 12 & Zea mays & Abu Arish & 4.23 & 3.4 \\
\hline 13 & Arachis hypogaea & Jazan & 5.54 & 30 \\
\hline 14 & Vicia faba & Jazan & 3.38 & 0.3 \\
\hline 15 & Sesamum indicum & Jazan & 7.3 & 39.1 \\
\hline 16 & Coffea Arabica & Jazan & 4.895 & 7.85 \\
\hline 17 & Medicago sativa & Ahad Almasarihah & 6.61 & 13.2 \\
\hline 18 & Hordeum vulgare & Jazan & 5.72 & 3.1 \\
\hline 19 & Gossypium herbaceum & Jazan & 6.51 & 11.65 \\
\hline 20 & Coffea Arabica & Abu Arish & 3.97 & 63 \\
\hline 21 & Sorghum bicolor (white) & Ahad Almasarihah & 4.69 & 59 \\
\hline 22 & Pennisetum glaucum & Jazan & 7.71 & 98 \\
\hline 23 & Sesamum indicum & Abu Arish & 5.88 & 82 \\
\hline 24 & Triticum $s p$ & Sabya & 4.1 & 0 \\
\hline 25 & Pennisetum glaucum & Abu Arish & 8.22 & 99 \\
\hline
\end{tabular}

Fig.2 Isolation Frequency and Relative Density \% of Fungi Isolated form Grains Samples.

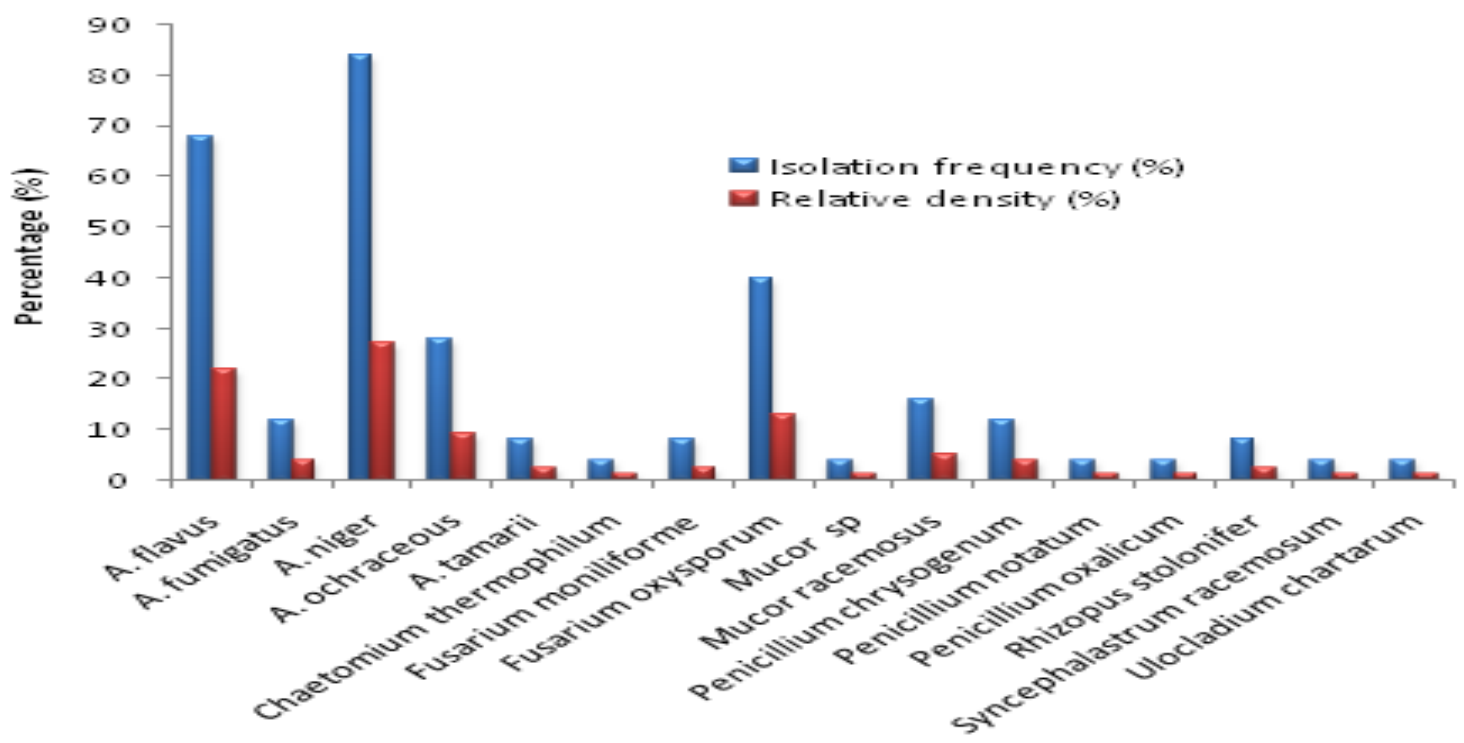


Table.2 Occurrence of Isolated Fungal Species in Collected Samples

\begin{tabular}{|l|c|c|c|c|c|c|c|c|c|c|c|c|c|c|c|c|c|c|c|c|c|c|c|c|c|}
\hline Sample No. & $\mathbf{1}$ & $\mathbf{2}$ & $\mathbf{3}$ & $\mathbf{4}$ & $\mathbf{5}$ & $\mathbf{6}$ & $\mathbf{7}$ & $\mathbf{8}$ & $\mathbf{9}$ & $\mathbf{1 0}$ & $\mathbf{1 1}$ & $\mathbf{1 2}$ & $\mathbf{1 3}$ & $\mathbf{1 4}$ & $\mathbf{1 5}$ & $\mathbf{1 6}$ & $\mathbf{1 7}$ & $\mathbf{1 8}$ & $\mathbf{1 9}$ & $\mathbf{2 0}$ & $\mathbf{2 1}$ & $\mathbf{2 2}$ & $\mathbf{2 3}$ & $\mathbf{2 4}$ & $\mathbf{2 5}$ \\
\hline A. tamari & - & - & - & - & - & - & - & - & - & - & + & - & + & - & - & - & - & - & - & - & - & - & - & - & - \\
\hline A. flavus & + & - & + & - & + & + & + & - & + & + & + & + & + & - & + & + & + & - & - & - & + & + & + & - & + \\
\hline A. fumigatus & + & - & + & - & - & - & - & - & - & - & - & - & & - & - & - & - & + & - & - & - & - & - & - & - \\
\hline A. niger & + & + & + & + & + & - & + & + & + & + & + & + & + & + & + & + & + & + & + & + & + & - & + & - & + \\
\hline A. ochraceous & - & - & - & + & + & - & - & - & - & - & + & + & & - & + & - & - & + & - & - & - & - & - & - & - \\
\hline C. thermophilum & - & - & - & - & - & - & - & - & - & - & - & - & - & - & - & - & - & - & - & - & - & - & - & - & + \\
\hline F. moniliforme & - & - & - & - & - & - & - & - & - & - & + & - & - & - & - & - & - & - & - & - & - & + & - & - & - \\
\hline F. oxysporum & + & + & - & - & - & - & + & - & - & + & + & - & - & - & - & + & + & + & + & + & - & - & - & - & - \\
\hline M. racemosus & - & - & - & - & + & + & - & - & - & - & + & - & - & - & - & - & + & - & - & - & - & - & - & - & - \\
\hline Mucor sp & - & - & - & - & - & - & - & - & - & - & - & - & - & - & - & - & - & +- & - & - & - & - & - & - & - \\
\hline P. chrysogenum & - & - & - & + & + & - & - & + & - & - & - & - & - & - & - & - & - & - & - & - & - & - & - & - & - \\
\hline P. notatum & - & - & - & - & - & - & - & - & + & - & - & - & - & - & - & - & - & - & - & - & - & - & - & - & - \\
\hline P. oxalicum & - & - & - & - & - & - & - & - & - & - & - & - & - & - & - & - & - & - & + & - & - & - & - & - & - \\
\hline R. stolonifer & - & - & - & - & - & - & - & - & + & - & - & - & + & - & - & - & - & - & - & - & - & - & - & - & - \\
\hline S. racemosum & - & - & - & - & - & - & - & - & - & - & - & - & + & - & - & - & - & - & - & - & - & - & - & - & - \\
\hline U.chartarum & + & - & - & - & - & - & - & - & - & - & - & - & - & - & - & - & - & - & - & - & - & - & - & - & - \\
\hline
\end{tabular}

A.: Aspergillus, C.: Chaetomium, F.: Fusarium, M.: Mucor, P.: Penicillium, R.: Rhizopus, S.: Syncephalastrum, U.: Ulocladium

Table.3 Aflatoxins and Zearalenone Production by A. flavus and F. oxysporium, Respectively under Different $\mathrm{pH}$

\begin{tabular}{|c|c|c|c|c|}
\hline \multirow{2}{*}{$\begin{array}{c}\text { Mycotoxin } \\
(\boldsymbol{\mu g} / \mathbf{k g})\end{array}$} & \multicolumn{4}{|c|}{$\mathbf{p H}$} \\
\cline { 2 - 5 } & $\mathbf{3}$ & $\mathbf{5}$ & $\mathbf{7}$ & $\mathbf{9}$ \\
\hline Aflatoxin B1 & 2.92 & 3.57 & 3.31 & 2.99 \\
\hline Aflatoxin B2 & 0.67 & 0.95 & 0.88 & 0.71 \\
\hline Aflatoxin G1 & 0.0 & 0.54 & 0.50 & 0.40 \\
\hline Aflatoxin G2 & 0.31 & 0.44 & 0.41 & 0.0 \\
\hline Total Aflatoxins & 3.90 & 5.50 & 5.10 & 4.10 \\
\hline Zearalenone & 60.5 & 52.9 & 37.5 & 13.9 \\
\hline
\end{tabular}

The obtained data on the frequency and relative percentage of fungi would be of a great importance for predicting the extent of pre- and postharvest infection and colonization of grains. The high frequency and relative percentage of $A$. niger and $A$. flavus species should be of primary concern for grains experts and policy makers in this region to minimize or prevent the economic losses caused by these fungi and also to reduce the exposure of human to mycotoxins. Broggi et al. (2007) stated that the major fungal species isolated was Fusarium verticillioides in maize in Argentina. Relative density of Aspergillus isolates was maximum for $A$. niger aggregates and $A$. ochraceous (30\% each) followed by A. flavus (26\%), A. parasiticus (11\%) and A. carbonarius (3\%) in maize meal (Saleemi et al., 2012). The fact that Aspergillus species was the most dominant species in the grains samples under study was reported by different investigators in different areas around the world especially in the warm and subtropical regions (Gashgari et al., 2010; Saleemi et al., 2012; Bosly and Kawanna, 2014 ).

Mould growth and mycotoxins production are determined by several environmental 
factors (temperature, composition of the gas atmosphere, substrate properties, including moisture content and water activity and $\mathrm{pH}$ ) that markedly affect the composition of mycoflora and in turn the mycotoxis in feeds (Marin et al., 2000). In the provided study $\mathrm{pH}$ among the critical factors was investigated for both aflatoxins and zearalenone as main mycotoxins produced by Aspergilli and Fusaria that were the most frequent fungal genera among all samples. Aflatoxins are known to be potent hepatocarcinogens in animals and human.

Therefore, the presence of toxigenic fungi and mycotoxins in grains stored for long periods of time presents a potential hazard to consumers health. Our result (Table 3) described that optimum $\mathrm{pH}$ for Aflatoxin $\mathrm{B} 1, \mathrm{~B} 2, \mathrm{G} 1$ and $\mathrm{G} 2$ production was 5 , then decreased. Aflatoxin G1 and G2 were inhibited at pH 3 and 9 respectively. Acidic pH 3 inhibited accumulation of AFG1 more than aflatoxins. The differential effect of $\mathrm{pH}$ on accumulation of aflatoxin G1 probably results from a decrease in activity of one of the biosynthetic enzymes involved in its formation. Buchanan and Ayres (1975) reported that maximal growth and aflatoxin production occurred at initial $\mathrm{pH}$ levels of $5.0,6.0$, and 7.0 respectively. Initial $\mathrm{pH}$ levels less than $\mathrm{pH} 6.0$ favored production of the aflatoxin $\mathrm{B}$, whereas levels greater than $\mathrm{pH} 6.0$ favored production of the aflatoxin G. Yabe et al. (1999) report that the cytochrome P450 monooxygenase necessary for aflatoxin $\mathrm{G} 1$ formation is more unstable than the P450 monooxygenase required for aflatoxin B1 formation. Zearalenone production decreased with increasing $\mathrm{pH}$, the optimum production $\mathrm{pH}$ was 9. El-Kady and El-Maraghy (1982) studied the effect of $\mathrm{pH}$ on zearalenone production by $F$. oxysporium in a $\mathrm{pH}$ range of 5 to 8 and their results suggests that zearalenone productivity reduced in alkaline $\mathrm{pH}$ values in agreement with the provided data;

However, they determined that optimum productivity was at $\mathrm{pH} 7$ while in the provided study it was $\mathrm{pH} 5$ this variation may be a result of $F$. oxysporium variety and/or variation in other cultivation conditions especially temperature as temperature directly affected the rate of zearalenone synthesis (Sherwoodand Peberdy, 1974).

\section{Acknowledgements}

The authors extend their appreciation to Deanship of Scientific Research at Jazan University for funding the work through the research group project No: 36/6/6423. Many thanks to Saudi Grains Organization (SAGO) and Grain Silos and Flour Mills Org. in Kingdom of Saudi Arabia for helping us for mycotoxin analysis.

\section{References}

Abdel-Azeem, S., Diab, M., El-Shahat, M. 2015. Ultra-high-pressure liquid chromatography-solid-phase clean-up for determining aflatoxins in Egyptian food commodities. J. Food Composition and Analysis, 44: 18-24.

Al-Shayaa, M.S., Baig, M.B., Straquadine, G.S. 2012. Agricultural extension in the Kingdom of Saudi Arabia: Difficult present and demanding future. J. Anim. Plant Sci., 22: 239-246.

Amezqueta, S., Schorr-Galindo, S., MurilloArbizu, M., Gonzalez-Peñas, E., De Cerain, A.L., Guiraud, J. 2012. OTAproducing fungi in foodstuffs: a review. Food Control, 26: 259-268.

Amira Abu-Taleb, M., Al-Julif, M.Z., AlArjani, A. 2012. Toxigenic fungi isolated from some food commodities and their pyhtotoxicity. Egypt. J. Exp. Biol., (Bot.) 8: 141-149.

Anke, H., Kolthoum, I., Zähner, H, Laatsch, 
H. 1980. Metabolic products of microorganisms. $185 . \quad$ The anthraquinones of the Aspergillus glaucus group. I. Occurrence,

Barnett, H.L., Hunter, B.B. 1998. Illustrated genera of imperfect fungi. APS press Minnesota.

Bennett, J.W., Klich, M. 2003. Mycotoxins. Clin. Microbiol. Rev., 16: 497-516.

Bokhari, F., Aly, M.M. 2009. Trials towards reduction of fungal growth and aflatoxin G1 production in Arabic coffee using different additives. Afr. $J$. Food Sci., 3: 68-76.

Booth, C. 1977. Fusarium. Laboratory guide to the identification of the major species. Commonwealth Mycological Institute.

Bosly, H.A., Kawanna, M.A. 2014. Fungi species and red flour beetle in stored wheat flour under Jazan region conditions. Toxicol. Industrial Health, 30: 304-310.

Broggi, L.E., González, H.H.L., Resnik, S.L., Pacin, A. 2007. Alternaria alternate prevalence in cereal grains and soybean seeds from Entre Rios, Argentina. Revista iberoamericana de micología, 24: 47.

Buchanan, R., Ayres, J. 1975. Effect of initial $\mathrm{pH}$ on aflatoxin production. Appl. Microbiol., 30: 1050-1051.

Bucheli, B., Diserens, P., Rychener, M., Tiéche, J.D., Trenkner, N. 1996. Untersuchungen zum Fusarienbefall und zur Mykotoxinbelastung des schweizerischen Brotgetreides der Ernten 1992-1994. Mitteilungen aus dem Gebiete der Lebensmitteluntersuchung und Hygiene, 87: 84-102.

Covarelli, L., Beccari, G., Salvi, S. 2011. Infection by mycotoxigenic fungal species and mycotoxin contamination of maize grain in Umbria, central Italy. Food and Chem. Toxicol., 49: 23652369.

Ehrlich, K.C., Kobbeman, K., Montalbano,
B.G., Cotty, P.J. 2007. Aflatoxinproducing Aspergillus species from Thailand. Int. J. Food Microbiol., 114: 153-159.

El-Kady, I., El-Maraghy, S. 1982. Screening of zearalenone-producing Fusarium species in Egypt and chemically defined medium for production of the toxin. Mycopathologia, 78: 25-29.

Enzyme Immunoassay for the quantitative analysis of aflatoxins. 1999. B1 Art. No.: R-1201 and Rida ${ }^{\circledR}$ aflatoxins column Art. No.: R 5002. R-Biopharm $\mathrm{GmbH}$, Darmstadt, Germany.

Frisvad, J. 1994. Classification of organisms by secondary metabolites. The Identification and Characterization of Pest Organisms, 303-320.

Frisvad, J.C., Thrane, U., Samson, R., Hoekstra, E. 2004. Mycotoxin production by common filamentous fungi. Introduction to food-and airborne fungi, 321-331.

Furlong, E.B., Soares, L.M.V., Lasca, C.C., Kohara, E.Y. 1995. Mycotoxins and fungi in wheat harvested during 1990 in test plots in the state of Sao Paulo, Brazil. Mycopathologia, 131: 185-190.

Gashgari, R.M., Shebany, Y.M., Gherbawy, Y.A. 2010. Molecular characterization of mycobiota and aflatoxin contamination of retail wheat flours from Jeddah markets. Foodborne Pathogens and Dis., 7: 1047-1054.

Hashem, A. 1990. Fungal flora of barley seeds in Saudi Arabia and its control. J. Food Protection, 53: 786-789.

Holmberg, T., Kaspersson, A., Göransson, B., Kozakiewicz, Z., Kramnäs, L. 1989. Aflatoxin production and tolerance to organic acids by Aspergillus flavus and Aspergillus parasiticus isolated from acid treated moist grain. Acta Agriculturae Scandinavica, 39: 449455.

Ioannou-Kakouri, E., Aletrari, M., Christou, E., Ralli, A., Koliou, A., Christofidou, M., Logrieco, A., Visconti, A. 2004. 
An Overview on Toxigenic Fungi and Mycotoxins in Europe, Springer Netherlands, USA. Isolation, identification and antimicrobial activity. Archives of microbial., 126: 223-230.

Klich, M. 2001. Identification of common Aspergillus species. United States Department of Agriculture. Agricultural Research Service, Southern Regional Research Center, New Orleans, LA.

Leslie, J.F., Summerell, B.A., Bullock, S. 2006. The Fusarium laboratory manual. Wiley Online Library.

Leszczynska, J., Maslowska, J., Owczarek, A., Ucharska, U.K. 2001. Determination of aflatoxins in food products by ELISA method. Czech J. Food Sci., 19: 8-12.

Lund, F., Frisvad, J.C. 2003. Penicillium verrucosum in wheat and barley indicates presence of ochratoxin A. $J$. Appl. Microbiol., 95: 1117-1123.

Maenetje, P.W., Dutton, M.F. 2007. The incidence of fungi and mycotoxins in South African barley and barley products. J. Environ. Sci. Health Part B, 42: 229-236.

Magnoli, C.E., Astoreca, A.L., Chiacchiera, S.M., Dalcero, A.M. 2007. Occurrence of ochratoxin A and ochratoxigenic mycoflora in corn and corn based foods and feeds in some South American countries. Mycopathologia, 163: 249260.

Marín, S., Magan, N., Abellana, M., Canela, R., Ramos, A., Sanchis, V. 2000. Selective effect of propionates and water activity on maize mycoflora and impact on fumonisin B 1 accumulation. J. Stored Products Res., 36: 203-214.

Montes, G., Reyes, M., Montes, R., Cantu, A. 2009. Incidence of potentially toxigenic fungi in maize (Zea mays L.) grain used as food and animal feed. CyTA-J. Food, 7: 119-125.

Muneera Al-Kahtarii, D. 2014. Isolation of Fungi and their 1VIycotoxin Extract from Stored Wheat and Other Grains Importer in Saudi Arabia. Amer. J. Food Technol., 9: 370-376.

Munkvold, G.P. 2003. Cultural and genetic approaches to managing mycotoxins in maize. Ann. Rev. Phytopathol., 41: 99116.

Nesci, A., Rodriguez, M., Etcheverry, M. 2003. Control of Aspergillus growth and aflatoxin production using antioxidants at different conditions of water activity and pH. J. Appl. Microbiol., 95: 279-287.

Palumbo, J.D., O'Keeffe, T.L., Abbas, H.K. 2008. Microbial interactions with mycotoxigenic fungi and mycotoxins. Toxin Rev., 27: 261-285.

Pitt, J., Taniwaki, M.H., Cole, M. 2013. Mycotoxin production in major crops as influenced by growing, harvesting, storage and processing, with emphasis on the achievement of Food Safety Objectives. Food Control, 32: 205215.

Raper, K.B., Fennell, D.I. 1965. The genus Aspergillus. The genus Aspergillus.

Saleemi, M.K., Khan, M.Z., Ahrar, K., Javed, I., HAsAN, Z.U., Hameed, M.R., Hameed, S., Mehmood, M.A. 2012. Occurrence of toxigenic fungi in maize and maize-gluten meal from Pakistan. Phytopathologia Mediterranea, 51: 219-224.

Samson, R.A., Hoekstra, E.S., Van Oorschot, C.A. 1981. Introduction to food-borne fungi. Centraalbureau voor Schimmelcultures.

Sarlin, T., Yli-Mattila, T., Jestoi, M., Rizzo, A., Paavanen-Huhtala, S., Haikara, A. 2006. Real-time PCR for quantification of toxigenic Fusarium species in barley and malt. Eur. J. Plant Pathol., 114: 371-380.

Schollenberger, M., Müller, H.M., Rüfle, M., Suchy, S., Planck, S., Drochner, W. 2005. Survey of Fusarium toxins in foodstuffs of plant origin marketed in Germany. Int. J. Food Microbiol., 97: 
317-326.

Sherif, S.O., Salama, E.E., Abdel-Wahhab, M.A. 2009. Mycotoxins and child health: The need for health risk assessment. Int. J. Hygiene and Environ. Health, 212: 347-368.

Sherwood, R.F., Peberdy, J.F. 1974. Production of the mycotoxin, zearalenone, by Fusarium graminearum growing on stored grain. I. Grain storage at reduced temperatures. J. Sci. Food and Agri., 25: 1081-1087.

Sreenivasa, M., Dass, R., Janardhana, G. 2010. Survey of postharvest fungi associated with sorghum grains produced in Karnataka (India). J. Plant Protection Res., 50: 335-339.

Tournas, V., Katsoudas, E. 2008. Microbiological quality of various medicinal herbal teas and coffee substitutes. Microbiology insights, 1: 47.

Velazhahan, R., Vijayanandraj, S., Vijayasamundeeswari, A., Paranidharan, V., Samiyappan, R., Iwamoto, T., Friebe, B.,
Muthukrishnan, S. 2010. Detoxification of aflatoxins by seed extracts of the medicinal plant, Trachyspermum ammi (L.) Sprague ex Turrill-Structural analysis and biological toxicity of degradation product of aflatoxin G1. Food Control, 21: 719-725.

Vrabcheva, T., Geßler, R., Usleber, E., Märtlbauer, E. 1996. First survey on the natural occurrence of Fusarium mycotoxins in Bulgarian wheat. Mycopathologia, 136: 47-52.

Yabe, K., Nakamura, M., Hamasaki, T. 1999. Enzymatic formation of G-group aflatoxins and biosynthetic relationship between G-and B-group aflatoxins. Appl. Environ. Microbiol., 65: 38673872.

Zhai, H.C., Zhang, S.B., Huang, S.X., Cai, J.P. 2015. Prevention of toxigenic fungal growth in stored grains by carbon dioxide detection. Food Additives \& Contaminants: Part A, 32: 596-603.

\section{How to cite this article:}

Marei A. Hamed, T. M Abdel Ghany, Nadeem I. Elhussieny, M.A.Nabih. 2016. Exploration of Fungal Infection in Agricultural Grains, Aflatoxin and Zearalenone Synthesis under pH Stress. Int.J.Curr.Microbiol.App.Sci. 5(4): 1007-1017. doi: http://dx.doi.org/10.20546/ijcmas.2016.504.115 